\title{
HOSPITALIZATION CHARACTERISTICS OF PATIENTS WITH MULTIPLE SCLEROSIS IN THE CLINICAL CENTER OF KRAGUJEVAC
}

Dragana Andric ${ }^{1}$, Snezana Radovanovic ${ }^{2}$, Svetlana Radevic ${ }^{2}$, Ivana Simic Vukomanovic ${ }^{2}$, Aleksandra Arnaut ${ }^{3}$, Sanja Kocic ${ }^{2}$

${ }^{l}$ Clinical Center Kragujevac, Department for organization, planning, evaluation and medical informatics, Kragujevac, Serbia

${ }^{2}$ University of Kragujevac, Serbia, Faculty of Medical Sciences, Department of Social medicine

${ }^{3}$ University of Kragujevac, Faculty of Medical Sciences, Department of Dentistry, Kragujevac, Serbia

\author{
KARAKTERISTIKE HOSPITALIZACIJE PACIJENATA OBOLELIH OD \\ MULTIPLE SILEROZE U KLINICIKOM CENTRU KRAGUJEVAC

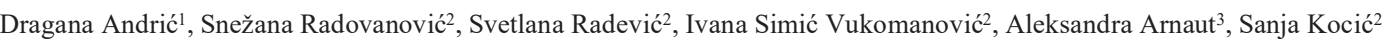 \\ ${ }^{l}$ Klinički centar Kragujevac, Služba za organizaciju, planiranje, evaluaciju i medicinsku informatiku, Kragujevac, Srbija \\ ${ }^{2}$ Univerzitet u Kragujevcu, Fakultet medicinskih nauka, Katedra za Socijalnu medicinu, Kragujevac, Srbija \\ ${ }^{3}$ Univerzitet u Kragujevcu, Fakultet medicinskih nauka, Odsek za stomatologiju, Kragujevac, Srbija
}

\begin{abstract}
Introduction/Goal: The goal of this paper is to analyze the hospitalization patterns of MS patients in the central and western Serbiain terms of hospitalization days, average length of inpatient stay, hospitalization rate, rehospitalizationpractices and treatment outcomes. Method: The research is designed as a retrospective descriptive epidemiological study. The study uses hospitalization reports from the Clinical Center of Kragujevacfor the time period ranging from January, 2007-December, 2014. Results: The study has revealed that during the given time period, 1.109 MS patients were hospitalized (745 female and 364 male). Women were significantly more numerous $(67.2 \%)(p<0.05)$. The average rate of hospitalization equaled 70.5 days per 100,000 citizens and was higher with women (94.8 per 100,000) than with men $(45.4$ per 100,000). The study has revealed a declining trend in hospitalization rates, inpatient days and average length of hospitalization. The number of standard inpatient days decreased while the number of hospitalizations in the day hospital increased ( $r=$ $0,905, p=0.002)$. In terms of age, the study has revealed that the number of hospitalizations decreased and hospitalization length increased with age $(p<0.05)$. There was a statistically significant inverse correlation between age and rehospitalization $(r=-0.138$, $p=0.000)$.In respect to treatment outcomes, in 93\% there was an improvement of the condition. Conclusion: The obtained results indicate that there is a need for establishing a register which could enable long-term monitoring of patients with MS which could eventually provide certain insights into the different aspects of the illness.
\end{abstract}

Keywords: multiple sclerosis, hospitalization report, length of inpatient stay, hospitalization rate, rehospitalization

\section{SAŽETAK}

Uvod/Cilj: Cilj ovog rada je analiza hospitalizacije pacijenata obolelih od multiple skleroze u centralnoj i zapadnoj Srbiji u pogledu broja bolničkih dana, prosečne dužine hospitalizacije, stope hospitalizacije, rehospitalizacije i ishoda lečenja. Metode: Istraživanje je dizajnirano kao retrospektivna deskriptivna epidemiološka studija. Istraživanje koristi izveštaje o hospitalizaciji Kliničkog centra Kragujevac za vremensko razdoblje od januara 2007. do decembra 2014. godine. Rezultati: Istraživanje je pokazalo da je u toku datog vremenskog perioda hospitalizovano 1109 pacijenata sa MS-om (745 ženskog i 364 muškog pola). Žene su bile znatno brojnije $(67,2 \%)(p<0.05)$. Prosečna stopa hospitalizacije iznosila je 70,5 dana na 100.000 stanovnika i bila je viša za žene (94.8 na 100,000) nego za muškarce (45.4 na 100,000). Istraživanje je pokazalo opadajući trend u stopama hospitalizacije, broju bolničkih dana i prosečnoj dužini hospitalizacije. Broj standardnih bolničkih dana se smanjio dok je broj hospitalizacija $u$ dnevnoj bolnici porastao ( $r=-0,905, p=0.002)$. U pogledu starosti pacijenata, studija je pokazala da se broj hospitalizacija smanjuje, a dužina povećava kako se povećava starost pacijenata $(p<0.05)$. Utvrđena je i statistički značajna negativna korelacija između starosti $i$ rehospitalizacije $(r=-0.138, p=0.000) . U$ pogledu ishoda lečenja zabeleženo je poboljšanje stanja pacijenata kod njih 93\%. Zaključak: Dobijeni rezultati pokazuju da postoji potreba za uspostavljanjem registra koji bi omogućio dugoročno praćenje pacijenata sa MS-om, a onda i uvid u različite aspekte bolesti.

Ključne reči: multipla skleroza, izveštaj o hospitalizaciji, dužina hospitalizacije, stopa hospitalizacije, rehospitalizacija
UDK: 616.832-004.2-08(497.11)"2007/2014"

Ser J Exp Clin Res 2020; 22 (1): 69-74 DOI: $10.2478 /$ sjecr-2019-0085 Corresponding author: University of Kragujevac, Faculty of Medical Sciences, Department of Social Medicine, Kragujevac, Serbi Phone: +38134306 800 Fax: +38134306 800 E-mail: cecaradevic@yahoo.com 


\section{INTRODUCTION}

Multiple sclerosis (MS), an autoimmune, chronic, and progressive disease, is the most common cause of non-traumatic neurological disability in young and middle-aged adults and thus it places a substantial burden on patients, families and the healthcare system $(1,2)$. According to WHO, there are more than 2.5 million MS patients worldwide with wide prevalence variations (3). The average prevalence of MS in the world for both genders equals 33 on 100,000 citizens with the highest prevalence rate in North America (140 on 100,000 citizens) and Europe (108 on 100,000), and the lowest prevalence rate in Africa (2.1 on 100,000) (4). It is estimated that MS affects 5,000 people in Serbia and the estimated prevalence rate is $65 \mathrm{MS}$ patients on 100,000 citizens (5).

Hospital admission rates in MS patients are higher than in general populations (6). In fact, they are more than twice as likely to visit a medical professional or to be hospitalized despite a significant downward trends over the past 25 years (2). The annual frequency of hospitalizations in the MS population reportedly ranges from $2.7 \%$ to $25.8 \%$. Some changes in MS care have occurred over the last 20 years. Diagnostic criteria have changed, diagnostic delays are now shorter, and disease-modifying therapies have been introduced (7). Despite these changes, patients with MS are relatively high users of the healthcare system (8). However, little is known about one of the most financially burdensome elements of their healthcare use - hospitalizations. The deeper understanding of their hospitalization patterns is an imperative in facilitating appropriate resource allocation; it can also help in the evaluation of disease-management strategies and can provide an indication of drug effectiveness (2).

The goal of this paper is to analyze hospitalization patterns of patients with MS in the Clinical Center Kragujevac with special emphasis on the number of hospitalization days, the length of inpatient stay, hospitalization rate, rehospitalizationpractices and treatment outcomes.

\section{METHODOLOGY}

\section{Study population, sample and instruments}

The research is designed as a retrospective, descriptive epidemiological study. The study uses hospitalization reports from the Clinical Center of Kragujevac which provides medical treatment for patients coming from the central and western Serbia. The selected time period ranges from the 1st of January, 2007 - the 31st of December, 2014 as a basic sample. The hospitalization reports have been used to create an electronic data basis in the Center for biostatistics and informatics at the Institute for Public Health Kragujevac. The total amount of hospitalization reports from the selected time periods equals 420,960. 8,017 hospitalization reports with multiple sclerosis (G35 group VI according to ICD-10) as a primary cause for hospitalization have been isolated.
Taking into consideration the flow of the illness, one part of the patients received medical treatment in the day hospital of the Clinic for Neurology to make sure that the therapy which modifies the natural flow of the illness was administered on regular basis (590 patients, i.e. 6,378 hospitalization reports). Those patients have been excluded from the study and only those patients, who were hospitalized due to certain impairments in their condition, i.e. relapse, have been included. The final sample equals 1,639 hospitalization reports or 1,109 hospitalized patients.

The study uses the following variables: gender, age, birth month, the number of hospitalization days, the number of rehospitalizations and treatment outcomes.

\section{Statistical analysis}

All statistical calculations have been performed using a commercial, standard software package SPSS, version 18.0. (The Statistical Package for Social Sciences, SPSS Inc, version 18.0, Chicago, IL). All the data are presented and analyzed by adequate mathematical-statistical methods appropriate for the data type. Chi-square $(\chi 2)$ has been used to contrast differences in the prevalence of categorial variables. The correlation between numerical variables has been tested with Pearson or Spearman correlation. Chi-Square, One-Variable test has been used to examine the correspondence between two distributions, the so-called correspondence test. Binomial test has been used to determine whether proportions of one category out of two are different from the specific value $(50 \%)$. All the results where the probability is less than $5 \%$ are considered to be statistically significant.

\section{RESULTS}

In the Clinical Center Kragujevac, during the given eightyear time period, 1.109 patients were hospitalized with neurologist-confirmed diagnosis of definite MS (745 female and 364 male). They achieved a total number of 1,639 hospitalizations. There is no statistically significant difference in the number of hospitalized patients per year of observation $\left(\chi^{2}=13.445, \mathrm{df}=7, \mathrm{p}=0.061\right)$ while the difference in the number of hospitalizations is statistically significant $\left(\chi^{2}=55.277\right.$, $\mathrm{df}=7, \mathrm{p}=0.005)$.

In terms of gender, among hospitalized patients women were significantly more numerous $(67.2 \%)$ than men $(32.8 \%)$ with the ratio of $2.04: 1(\mathrm{p}<0.05)$.

The average age of hospitalized patients equals 41.5 years $(\mathrm{SD}=10.948)$. The youngest patient was 15 while the oldest was 83 years old. The average age of hospitalized women was $41(\mathrm{SD}=11.094)$ while the average age for men was 42 $(\mathrm{SD}=10.618)$.

In terms of age groups, the majority of hospitalized patients were in the age group from $40-49(31.3 \%)$, then from $30-39(30.1 \%)$. The lowest number of patients was in the age group $70+(0.8 \%)$. The highest number of females belonged to an age group from 30 to $39(32.3 \%)$ while the 
highest number of males was in the age group 40 to 49 years old $(35.4 \%)$ (Chart 1). The difference in the distribution of patients based on their gender in comparison to the age groups is not statistically significant $\left(\chi^{2}=8.308, \mathrm{df}=6\right.$, $\mathrm{p}=0.21)$.

Chart 1. The distribution of hospitalized patients according to gender and age

\section{Women Men}

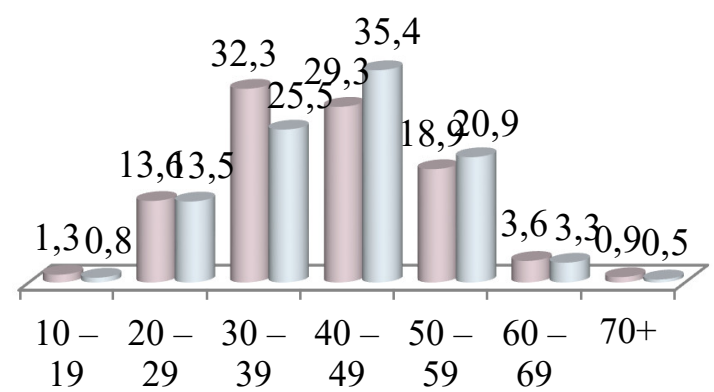

The average rate of hospitalization in the given period equaled 70.5 days per 100,000 citizens where the average rate of hospitalization of women $(94.8$ per 100,000$)$ was significantly higher in respect to hospitalization rate of men (45.4 per 100,000). The hospitalization rate analysis has revealed that there was a declining trend which was more emphasized in case of females (Chart 2).

Chart 2. Hospitalization rate per 100,000 citizens, total and according to gender, $2007-2014$

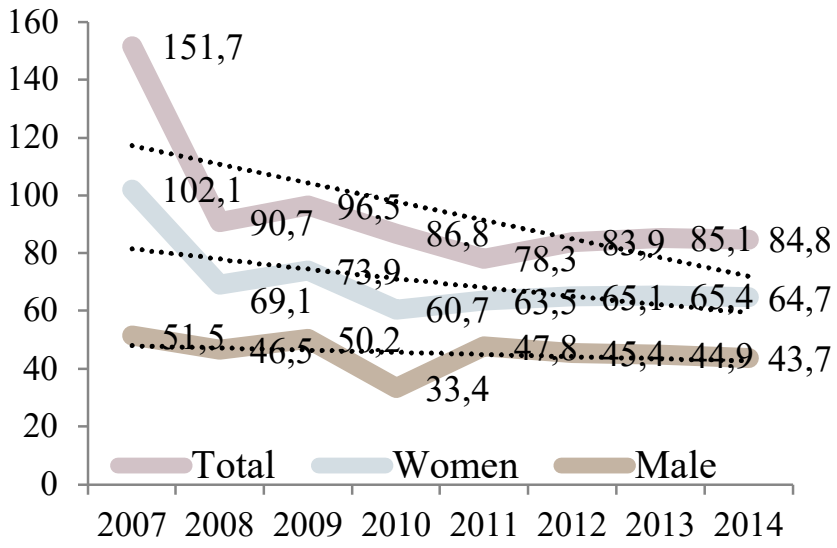

From the total number of 1,109 patients, 757 patients had only one hospitalization (503 women and 254 men), while 352 patients had more than one hospitalization (242 women and $110 \mathrm{men}$ ). Women, in average, were hospitalized 1.5 times while men were hospitalized 1.4 times. There is no statistically significant difference in genders in terms of the number of hospitalizations $(\mathrm{p}>0.05)$.

However, there is a statistically significant inverse correlation between age and rehospitalization $(\mathrm{r}=-0.138, \mathrm{p}=0.000)$. As the age of the patients grew, the number of their hospitalizations decreased, i.e. the younger patients were more frequently rehospitalized. The most commonly hospitalized patients belonged to the age groups from $30-39$ and from $40-49$.

The total number of inpatient days equaled 19,264. Women had 13,548 and men had 5,716 inpatient days. The number of hospitalization days was the highest during the first year of the observation (4,942 days) and the lowest during the last year (1,767 days). The difference is statistically significant $\left(\chi^{2}=92.985 \mathrm{df}=7, \mathrm{p}=0.000\right)$. The decline in the number of inpatient days has been also observed in respect to gender. The hospitalization length was reduced from 16.5 days in the first year to 11.7 in the last year of the observation (Table 1).

Table 1. The number of inpatient days (IP days) with average length of hospitalization (AHL)

\begin{tabular}{ccccccc} 
& Total & \multicolumn{3}{c}{ Women } & \multicolumn{2}{c}{ Men } \\
\hline $\begin{array}{c}\text { Year of } \\
\text { obser- } \\
\text { vation }\end{array}$ & $\begin{array}{c}\text { IP } \\
\text { days }\end{array}$ & $\begin{array}{c}\text { AH } \\
\text { L }\end{array}$ & $\begin{array}{c}\text { IP } \\
\text { days }\end{array}$ & AHR & $\begin{array}{c}\text { IP } \\
\text { days }\end{array}$ & AHL \\
\hline 2007 & 4.942 & 16,5 & 3.817 & 16,8 & 1.125 & 15,4 \\
2008 & 2.265 & 11,3 & 1.533 & 11,4 & 732 & 11,1 \\
2009 & 2.225 & 10,4 & 1.460 & 10,3 & 765 & 10,7 \\
2010 & 2.089 & 11,9 & 1.544 & 12,1 & 545 & 11,6 \\
2011 & 1.941 & 10,7 & 1.250 & 10,9 & 691 & 10,3 \\
2012 & 2.061 & 10,9 & 1.324 & 10,7 & 737 & 11,3 \\
2013 & 1.974 & 10,4 & 1.393 & 11,1 & 581 & 9,1 \\
2014 & 1.767 & 9,4 & 1.227 & 9,8 & 540 & 8,7 \\
Total & 19.26 & 11,7 & 13.54 & 12,1 & 5.716 & 11,1 \\
\hline
\end{tabular}

The average length of hospitalization for females was 12.1 days and for males 11.1 days. There is no statistically significant correlation between gender and hospitalization length $(\mathrm{p}>0,05)$.

There is a statistically significant correlation between age and hospitalization length $(\mathrm{p}<0.05)$. Hospitalization length increases with age. The longest hospitalizations have been recorded with patients who are 80 years old or more, while the shortest hospitalization length has been recorded in the age group from $10-19$ (Table 2).

The ratio of standard inpatient days and hospitalization days in the day hospital was inversely proportional. During the years, the number of standard inpatient days was decreasing while the number of hospitalizations in the day hospital was increasing $(r=-0,905, \mathrm{p}=0.002)$ (Chart 3). 
Table 2. The average hospitalization length (AHL) according to age groups

\begin{tabular}{ccccccc}
\hline & \multicolumn{2}{c}{ Total } & \multicolumn{2}{c}{ Women } & \multicolumn{2}{c}{ Men } \\
\hline Age & IP & AHL & IP & AHL & IP & AHL \\
groups & days & days & days & \\
$10-19$ & 176 & 8,8 & 124 & 8,4 & 52 & 7,4 \\
$20-29$ & 3073 & 11,9 & 2307 & 12,7 & 766 & 9,9 \\
$30-39$ & 6505 & 12,6 & 4915 & 12,8 & 1590 & 11,9 \\
$40-49$ & 5556 & 11,2 & 3541 & 11,4 & 2015 & 10,7 \\
$50-59$ & 3319 & 11,4 & 2244 & 11,5 & 1075 & 11,3 \\
$60-69$ & 516 & 11,5 & 327 & 10,5 & 189 & 13,5 \\
$70-79$ & 74 & 9,25 & 59 & 9,5 & 15 & 15 \\
$80+$ & 45 & 22,5 & 31 & 31 & 14 & 14 \\
Total & 19.26 & 11,7 & 13.54 & 12,1 & 5.71 & 11,1 \\
& 4 & & 8 & & 6 & \\
\hline
\end{tabular}

Chart 3. The ratio of standard inpatient days and hospitalization days in the day hospital

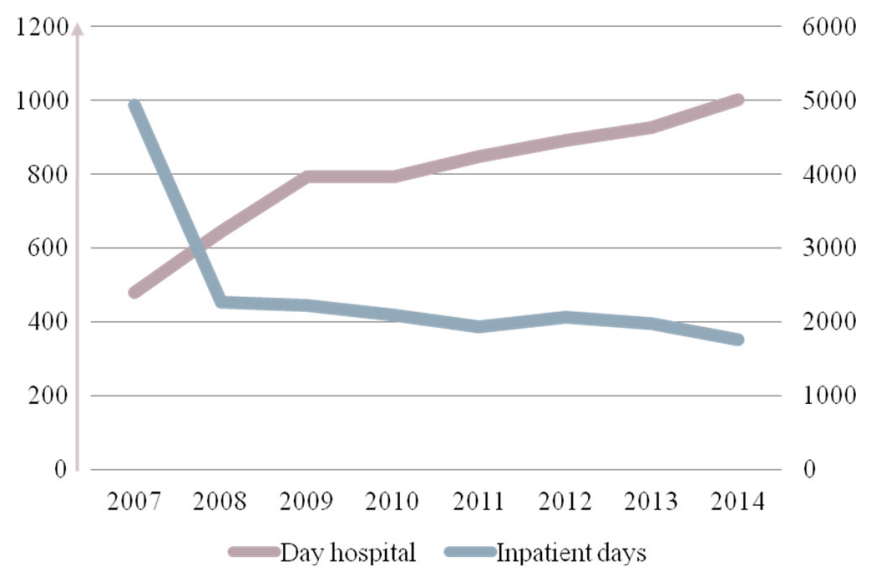

In respect to treatment outcome, in majority of cases the study has detected an improvement of the condition of the patients $(93.7 \%)$.

\section{DISCUSSION}

The first goal of the study was to examine demographic characteristics of hospitalized patients (gender and age) like important indicators of MS occurrence. In the Clinical Center Kragujevac, $67.2 \%$ of women and $32.8 \%$ of men were hospitalized with the ratio of 2.04:1. The almost similar ratio of hospitalized patients in respect to gender has been detected on the level of the whole country where 4,447 people were hospitalized in 2012 with $67.8 \%$ of females and $32.2 \%$ of males (the ratio is 2:1). The results of this study in terms of gender distribution are in accordance with the results obtained for neighboring countries and the world: Croatia (2.7:1), Slovenia (2.3:1), Romania (2.1:1) and Bosnia and Herzegovina (2.3:1) (9,10). In Canada, where the prevalence of MS is the highest in the world, during the time period ranging from 1996 to 2006, the ratio of hospitalizations between women and men was 2.6: 1 (11).
The average age of females treated at the Clinical Center Kragujevac was 41 , and 42 for male patients. The result of the studies conducted for the other countries of the world are similar to the result obtained through this study. Namely, the average age of hospitalized patients ranges from $33-42$ for women and from $39-46$ for men (10-12). The results of the study indicate that hospitalized women are younger in respect to men which is completely expected taking into consideration that females get affected by MS at earlier age in comparison to males (13). The analysis of the age groups according to gender reveals that the highest percentage of hospitalized women is from $30-39$ years old $(32.3 \%)$ while the highest percentage of men is aged between $40-49$ (35.4\%). The distribution according to age groups correlates with the data obtained on the national level. In Serbia, in 2012, the highest percentage of hospitalized women was $30-39$ years old (33\%) while for men it was the age group from $40-49$ (27.2\%). The distribution of hospitalized patients according to their age and gender varies among countries. In Croatia and Romania the highest number of hospitalized men belongs to the same age group as in Serbia but the highest number of women belongs to older age group $(50-59)$. In Slovenia, the majority of women were in the same age group as female MS patients in Serbia, but hospitalized male MS patients were in the younger group ( $30-39$ years) (9).

The second goal of this paper was to analyze hospitalization with special emphasis on hospitalization rate, rehospitalization, the number of inpatient days, hospitalization length and treatment outcomes.

The average hospitalization rate in the given time period was higher in female patients ( 94.8 per 100,000 citizens) than in male patients (45.4 per 100,000 citizens). In a large study conducted in England which dealt with geography of MS hospitalizations on the sample of 56,681 patients $(39,006$ women and 17,562 men) hospitalized during the period ranging from $1999-2005$, the obtained rates were higher in female (22 on 100,000 citizens) than in male patients (10.4 on $100,000)(14)$. This is similar to our results. Contrary to our results, a study conducted in Canada on the sample of 5,138 hospitalized patients from 1998 - 2006 has revealed that women have lower hospitalization rate than men (2). It is possible that faster progression of the illness detected in men is the reason for such results, i.e. there are bigger chances of physical comorbidity with male MS patients. According to the data from 2012 in the Republic of Serbia, the hospitalization rate was 61.8 per 100,000 citizens (women 81.6 and men 40.18) while the hospitalization rate in the surrounding countries is lower: Croatia -51.9 ; Slovenia -12.9 ; Romania 15.3. The similar rates have been detected in the Scandinavian countries like Denmark (35.5) and Finland (18.9) $(9,15)$.

One of the aims of the study was to determine the correlations between gender/age with rehospitalization patterns. The study has revealed that there is no correlation between gender and rehospitalization while there is a correlation between age and rehospitalization. Namely, younger patients are more often rerhospitalized. The possible explanation may 
lie in the fact that there were certain patients who had been diagnosed with MS recently and those patients with MS in its early stages are more prone to relapses which then gradually decline over time (13). There are no studies on the possible correlations between gender/age and rehospitalization frequency so there is no data to compare with the results of this study. This is the additional significance of this research.

In the given time period, every patient was hospitalized 1.5 times in average which is close to an average on the global level (16). The results of a study conducted in Germany reveal that every MS patients is hospitalized 0.57 times (17) and in England the same value is 1.96 times in average (2).

The average length of hospital treatment in the given time period was 11.7 days. In respect to gender, our results reveal that women spent 12.1 days while men spent 11.1 days in average. The study has revealed that there are no correlations between gender and hospitalization length. However, the results show that there is a positive correlation between age and hospitalization length. Older patients tend to be hospitalized longer which can be explained by higher comorbidity and higher functional addiction of older patients. The longest hospitalization have been detected in the age group $80+$ (women 31 and men 14 days) and the shortest in $10-19$ (women 8.4 and men 7.4 days). The similar results were obtained in a study conducted in Canada where older people, who have MS longer, stayed in hospitals longer amounts of time; gender and clinical form of the illness proved not to be influential in terms of hospitalization length in this study (2). The results show that the values of average length of hospitalization in the Clinical Center Kragujevac (the population of the Central and West Serbia gravitates towards it) are more similar to the results in surrounding countries and some countries of the Western Europe (France - 4.9; Bulgaria - 5; Spain - 6.7; Romania - 6.9; Slovenia - 7.1; Hungary - 10.7; Croatia -13.6 and Finland -18.6$)$ than to the results on the national level- 23 days $(9,15)$.

The differences in hospitalization rates and hospitalization length between countries may be the result of the differences in economic level and the introduction of the new system of financing medical institutions through the diagnostically-related groups (DRGs). The advantage of DRGs is that it motivates the reduction of costs per patient through: the reduction of hospital treatment length, diagnostic and treatment procedures and the focus on day hospitals.

One of the aims of this study was to examine the relations between standard inpatient days and a day hospital treatments. The increase in day hospital visits is directly linked to the decrease in inpatient days. It is a result of the fact that patients who are already diagnosed with MS during the further flow of the illness are more commonly treated in day hospitals where during the relapse they are administered pulse corticosteroid and immune-modular therapy. In any case, treatments in day hospitals have positive impact on life quality of patients and reduce the costs of standard hospital treatments.

This study examined hospitalization patterns of patients with MS in Clinical Center Kragujevac. This may be a limitation in generalizing the findings. However, the main limitation of this study is that there is no registry of patients with multiple sclerosis that could be used as a gold standard for making comparisons to the data from hospitalization reports. Despite these limitations, this is the first study conducted in MS hospitalization patterns in Serbia. Electronic hospitalization reports are very important data source about hospitalized patients. The possibility of making errors while entering data is reduced to a minimum because there are control mechanisms in the application forms.

In Serbia, there are no regional or national Registers for MS which makes long-term monitoring difficult. Such registers have been founded in Denmark, Norway, Sweden, Italy (The Multiple Sclerosis Database Network), USA (NARCOMS Register and the National Register for MS) and Germany $(18,19)$. The registers for MS follow the medical condition of the diseased during time and take care of the implementation of guides for their care and treatment, the evaluation of their progress and strive to detect and overcome all the lacks and deficiencies in providing medical treatment to people suffering from MS.

\section{CONCLUSION}

Based on the results obtained through this study, the following conclusions can be drawn:

1. Demographic characteristics of MS patients, like gender and age, are strong indicators of MS occurrence. Hospitalized patients are more commonly women and middle-aged people.

2. The average hospitalization rate for women is twice higher than for men.

3. Gender has no influence on rehospitalization. Younger patients are more commonly hospitalized.

4. The average inpatientdays is similar for both genders.

5. Hospitalizations of older people last longer.

6. The increase in treating patients in day hospitals is directly related to the reduction in hospitalization length.

7. In majority of cases, a treatment results in an improvement of a medical condition.

The obtained results indicate that there is a need for establishing a register which could enable long-term monitoring of patients and deepen the understanding of MS by providing certain insights into the different aspects of the illness. This could further help in making decisions relevant for MS to different institutions included in the process. 


\section{CONFLICT OF INTEREST}

All authors declare no support from any organisation for the submitted work; no financial relationships with any organisations that might have an interest in the submitted work; no other relationships or activities that could appear to have influenced the submitted work. The authors declare that they have no conflict of interest.

\section{REFERENCES}

1. Dehghan M, Ghaedi-Heidari F. Environmental Risk Factors for Multiple Sclerosis: A Case-control Study in Kerman, Iran. Iran J Nurs Midwifery Res. 2018;23(6):431-436.

2. Evans C, Kingwell E, Zhu F, Oger J, Zhao Y, Tremlett $\mathrm{H}$. Hospital admissionsand MS: temporal trends and patient characteristics. Am J Manag Care 2012;18(11):735- 42.

3. Liu X, Cui Y, Han J. Estimating epidemiological data of Multiple sclerosis using hospitalized data in Shandong Province, China. Orphanet J Rare Dis. 2016;11(1):73.

4. Atlas of MS database for 2013.[Internet]. London: Multiple Sclerosis International Federation; 2013 [cited: 2016. Jan 27]. Available from:http://www.msif.org/

5. Toncev G, Miletic Drakulic S, Knezevic Z, Boskovic Matic T, Gavrilovic A, Toncev S, Drulovic J, Pekmezovic T. Prevalence of multiple sclerosis in the Serbian district Sumadija. Neuroepidemiology. 2011;37(2):102-6.

6. Pirttisalo AL, Sipilä JOT, Soilu-Hänninen M, Rautava P, Kytö V. Adult hospital admissions associated with multiple sclerosis in Finland in 2004-2014. Ann Med. 2018;50(4):354-360.

7. Marrie RA, Elliott L, Marriott J, Cossoy M, Blanchard J, Tennakoon A, Yu N. Dramatically changing rates and reasons for hospitalization in multiple sclerosis. Neurology. 2014;83(10):929-37.

8. Hawton AJ, Green C. Multiple sclerosis: relapses, resource use, and costs. Eur J Health Econ. 2016 Sep;17(7):875-84.

9. European Hospital Morbidity Database [Internet] Copenhagen: World Health Organization Regional Office for Europe 2015 [cited: 2016. Mar 17]. Available from: http://data.euro.who.int/hmdb/.
10. Euphrosyni K, Aikaterini F, Thalia K, Stavros B. Epidemiologic Data of Multiple Sclerosis in Northern Greece during the Last Thirty Years (1979-2008). American Journal of Epidemiology and Infectious Disease2013;1(1):1-7.

11. Willer CJ, Dyment DA, Risch NJ, Sadovnick AD, Ebers GC.Canadian Collaborative Study Group.ProcNatlAcadSci U S A. 2003;100(22):12877-82.

12. Maryam R, Soheil M, Maryam B, Sabbagh S. Prevalence, Demographics and Clinical Characteristics of Multiple Sclerosis in North of Khuzestan Province, Iran Jentashapir J Health Res. 2015; 6(5): e23831.

13. Drulović J, Mostarica Stojković M, Pekmezović T, Pravica V, Filipović S, Kisić Tepavčević D i ost. Multiple sclerosis. Beograd: Medicinski fakultet Univerziteta u Beogradu, 2013. (Serbian)

14. Ramagopalan SV, Hoang U, Seagroatt V, Handel A, Ebers GC, Giovannoni G, Goldacre MJ. Geography of hospital admissions for multiple sclerosis in England and comparison with the geography of hospital admissions for infectious mononucleosis: a descriptive study. J Neurol Neurosurg Psychiatry. 2011;82(6):682-7.

15. Eurostat.Discharges from hospitals [Internet]. Luxembourg: European Commission, Eurostat 2015 Database. [cited: 2016. Feb 1]. Available from: http://ec.europa.eu/eurostat.

16. Patzold U, Pocklington RP. Course of multiple sclerosis. First results of a prospective study carried out of $102 \mathrm{MS}$ patients from 1976-1980. ActaNeurolScand 1982;65:248-66.

17. Seiffert A, Dippel F, Sommer G, Holz B, Trottmann M. Hospital stays of Multiple sclerosis patients in Germanuy - reasons, frequencies, duration and impact on drug therapy. Research Gate2012; 15(7).

18. Čovičković Šternić N. National Guide of Good Clinical Practice for Diagnosing and Treating Multiple Sclerosis. Belgrade: Ministry of Health, 2013.(Serbian)

19. Dobrinčić M. Guide through Multiple Sclerosis. Beograd: Serbian Association for Multiple Sclerosis, 2009.(Serbian) 